\title{
MIGRATION, INCOME DISTRIBUTION, AND WELFARE UNDER ALTERNATIVE INTERNATIONAL ECONOMIC POLICIES
}

\author{
William P. Travis* \\ I \\ INTRODUCTION
}

American international economic policy is an extensive system that includes tariffs, import quotas, voluntary export-limiting agreements with foreign countries, certain restrictions on capital inflows and outflows and on the export of technology, immigration laws, and foreign aid undertakings. In its broad outlines this system restricts the importation of goods intensive in unskilled labor and severely restricts the immigration of unskilled workers. It also encourages in various ways the immigration of skilled workers while placing few other remaining restrictions on imports of products which are intensive in land, capital, or skilled labor, generally encouraging other countries to trade freely among themselves and with the United States.' The liberalization of international trade and payments during the past twenty years has greatly increased international interdependency. Effective restraints on the movement both of unskilled workers and of those goods intensive in their services nonetheless remain, as do restrictions on capital inflow and imports generally in the less developed countries.

This paper will explore the consequences of changing or relaxing the various restrictions on the movement of goods, people, and capital between the United States and Latin America. The effects of different policies on the levels of migration of both skilled and unskilled workers, the flows of goods of various types, inter-

\footnotetext{
Copyright (C) 1983 by Law and Contemporary Problems

- Professor, Department of Economics, Indiana University; published posthumously.

1. U.S. tariffs are reported in U.S. TARIFF COMMISSION, U.S. CUSTOMS DUTIES ANNOTATED FOR Statistical RePORTING PUR poses, July 1962. Some studies that compute indexes of tariff protection by categories similar to those used here are B. Vaccara, EMPloyment and OUTPUT In PRotected MANUFACTURING Industriks (1960); Travis, A Critical Rehabilitation of Effective Protection Theory, in EFFEcTIVE Tarirf Protection 217 (1971); and Travis, Production, Trade, and Prolection When There are Many Commadities and Two Factors, 62 AM. ECON. REV. 87, 101 (1972). For the effects of other forms of restrictions on U.S. imports, see Baldwin, Nontariff Distortions of Intemational Trade, in 1 UNITED STATES INTERNATIONAL ECONOMIC POLICY IN AN INTERDEPENDENT WORLD 641 (1971).

For analyses of protectionism in Latin American countries, see The Structure of Protection IN Developing Countries (B. Balassa ed. 1971); Macario, Protectionism and Industrialization in Latin America, 9 ECON. Bull. fOR LATIN AM. 61 (1964); I. LiTtLe, T. Scitovsky \& M. SCOTT, Industry AND TRADE IN Some Developing Countries (1970); D. Schydlowsky, Latin American Trade Policies in the 1970's: A Prospective Appraisal (Paper presented at the Columbia University Conference on International Economic Development, Williamsburg, Virginia and New York, Feb. 1970).
} 
national investment, relative prices, and real levels of income both of countries and of important classes of factor suppliers will be examined.

The United States allows the immigration of skilled workers from poor countries but severely limits the immigration of their unskilled workers. Would it be better for the poor countries if the United States restricted entry of their skilled workers? Their emigration certainly drains the home countries of the resources devoted to their education. It also deprives local industries of their services and must lower the productivity of the unskilled workers who remain. Moreover, the basic injustice whereby one social segment pays for the education of another which then leaves the country to seek much higher rates of pay is only too apparent. In the long run it is likely to lead to a reduction of educational activity in the poor countries.

According to a recent documentation of the emigration of skilled workers from Latin America, about one-third of the graduates of universities and superior professional schools emigrate to the United States. ${ }^{2}$ This is a serious matter, as evidenced by the fact that in 1965 only 700 engineers and scientists were doing fulltime university teaching and research in all of Latin America. ${ }^{3}$ Thus, too few nationals are available there to create or adapt new technology for economic development. The lack of development, in turn, exacerbates the pressure for emigration to the United States.

Migration of skilled and unskilled labor, the international flow of capital, international trade in goods, and international differences in technology are all intimately interrelated, such that none of these areas can be fruitfully studied independently of all the others. For this paper, therefore, a numerical, general equilibrium model was constructed to capture the basic features of the economic relationship between the United States and Latin America. These features include the large size and high level of technology of the American economy, its wealth of capital stock and land relative to Latin America, and the migration, investment, and trade policies of the two trading partners.

The main questions posed in the investigation were the following:

1) Given the restrictions on unskilled labor immigration to the United States, would it be better to prohibit skilled labor immigration also?

2) What would be the impact of allowing both types of labor to migrate freely to the United States?

3) If Latin American countries cannot stem the emigration of skilled labor, should they reduce their educational efforts rather than watch the fruits of those efforts drain away to another country?

4) Would freeing trade and foreign investment of artificial restrictions substitute at least partially for worker migration, or would it also be necessary to transfer U.S. technology abroad in order to reduce the pressure for migration?

Several of the results turned out to be quite surprising. The model indicated

2. Calculated from information in The LATIN AMERican BRain DRAin In THE UNITED STATES 1624 (C. Cortes ed. 1980).

3. Id. at 8 . 
that skilled migration depresses the unskilled wage rate in the United States just as does unskilled migration, even though skilled and unskilled workers are cooperative inputs. Unrestricted unskilled labor migration to the United States would also greatly lower the welfare of those workers as compared to the present situation. Technological transfer to Latin America would greatly raise the joint income of both countries, but it would also lower the real unskilled wage rate of both countries.

The exact magnitudes of the changes reported depend, of course, on the particular numbers chosen to represent the demand, conditions, endowments, technologies, tariffs, and transportation costs affecting the countries. General arguments for the main qualitative conclusions are therefore provided as well.

The results indicate that the immigration problem has no solution purely in its own terms. It must be treated as a part of overall foreign economic policy aimed ultimately at the technological improvement of the United States' poorer neighbors. Otherwise, pressure for illegal immigration will be a permanent feature of our relations with those countries.

This paper is organized as follows: The first section explains (in terms of a simple economic model) why the United States is technologically superior to most other countries. This digression is important because technological disparity is at the root of the migration problem. When migration and trade are both free, all mobile factors, seeking higher rates of remuneration, tend to gravitate to the country or region of best technology. Such migration distorts the proportions of mobile to immobile factors in each region and is inefficient relative to the situation in which technology is evenly spread. A careful definition and explanation of technological disparity also serves to remove some of the hidden emotional blocks to the clear discussion of the relations between rich and poor countries.

The second section of the paper sets up the model of economic relations as between technologically disparate countries under numerical assumptions appropriate to the United States and its Latin American neighbors. This section also describes four experiments that were performed involving migration between technologically disparate countries. The third section of the paper details policy experiments performed on the model which were designed to explore superior alternatives to the migration of both unskilled and skilled labor. The fourth section comments briefly on the most important findings of those experiments.

\section{Technological Disparity and the Pressure for Migration}

The immediate reason for a factor of production to migrate is for its owners to obtain a higher real rate of remuneration. If technology were identical internationally, as assumed in the leading current theory of international trade, ${ }^{4}$ this

4. This is the so-called Heckscher-Ohlin Trade Theory. It derives from Heckscher, The Effects of Foreign Trade on the Distribution of Income, EKONOMISK TIDSKRIFT (1919) and B. OHLIN, INTERREGIONAL AND INTERnATIONAL TRADE (1933). The theory assumes that tastes and production functions are internationally identical, that production functions are homogeneous and subject to diminishing marginal returns to factor inputs, and that trade is free of tariffs and transport costs. It predicts that countries will export 
reason would not exist, provided that capital and goods moved internationally without tariffs or excessive transportation costs. When a country is technologically superior, trade in goods and capital services cannot equalize earnings internationally because the country will specialize exclusively in the production of goods intensive in the mobile factors. ${ }^{5}$ The United States exhibits this pattern. It attracts capital and both skilled and unskilled labor from overseas, while most of its overseas investment is direct, involving the transfer of U.S. technology to plants in foreign countries. ${ }^{6}$ In order to assess whether or not this fundamental cause of immigration is likely to remain, it is necessary to explain how and why the United States is technologically superior.

Technology is here given the narrowest possible interpretation. It refers only to the observable relationships between inputs and outputs in distinct production processes. Let $y$ stand for the quantity of the output of such a process and $x$ for its one or more inputs. The production process is then described by the equation $y=$ $a x_{1}$, where the coefficient $a$ represents the level of technology (a higher value of $a$ means that $x$ is more efficiently transformed into $y$ ) and where $1 / a$ therefore expresses the amount of $x$ needed to produce a unit of $y$. Better technology means that such input requirements are reduced.

Next assume that the coefficient $a$ is itself subject to improvement via the input of resources $x_{2}$. Let the equation $a=x_{2}$ ' represent the production of new knowledge as a function of $x_{2}$ - the resources devoted to research and development ( $R \&$ D). In this equation the exponent $e$ indicates the elasticity of new knowledge with respect to $\mathbf{R} \& \mathbf{D}$. It is assumed to be less than unity and greater than zero. Because total resources for producing $y$ are equal to $x=\left(x_{1}+x_{2}\right)$, we have $y=a(x$ $\left.-x_{2}\right)=x x_{2}^{e}-x_{2}^{e+1}$. The problem facing the producer of $y$ is to determine the best level of $x_{2}$ or $\mathrm{R} \& \mathrm{D}$ in order to maximize the output of $y$ for his given total resources $x$. This is done by differentiating the expression for $y$ with respect to $x_{2}$, setting that derivative equal to zero, and solving for $x_{2}$ in terms of $x$ :

$$
\frac{d y}{d x}=e x x_{2}^{e-1}-(e+1) x_{2}^{e}=0
$$

The appropriate manipulations yield the following primary results:

$$
\text { (i) } x_{2}=\frac{e x}{(e+1)}
$$

products intensive in their relatively abundant factors and thereby-to some extent, at least-alleviate the international factor-price differentials that would incite migration of the mobile factors. The celebrated factor-price equalization theorem states that factor prices will equalize completely under the HeckscherOhlin assumptions so long as the countries involved continue to produce in common and to trade at least as many products as there are primary factors. See Lerner, Factor Prices and Intemational Trade 19 ECONOMICA 1 (1952); Lerner Intemational Factor Price Equalization Once Again, 59 ECON. J. 181 (1949); W. Travis, The Theory of Trade and Protection $1-112$ (1964).

5. This proposition is illustrated in the experiments below that allow capital, labor, and skilled labor to migrate freely between the two technologically disparate countries. The proposition is therefore important for the theory of migration, but has appeared only briefly in the international trade literature. For an early statement, see Jones, The Role of Technology in the Theony of Intemational Trade, in THE TECHNOLOGY Factor in International Trade 73, 83, 84 (R. Vernon ed. 1970).

6. For a full description of the patterns of U.S. foreign investment and trade, see Branson, Trends in United States Trade and Investment, in The AMER ICAN EconOMY IN TRANSITION 183 (M. Feldstein ed. 1980). 
(ii) $a=\left(\frac{e}{e+1}\right)^{e} x^{e}$
(iii) $y=\frac{e^{e} x^{e+1}}{(e+1)^{e+1}}$

Because the coefficient of $x^{e+1}$ in equation (iii) is a constant (depending only on the elasticity $e$ ), and because $e$ lies between zero and one, the comprehensive production function $y=f(x)$ for $y$ is subject to increasing returns to scale. Outputs $y$ increase in greater proportion than inputs when $\mathrm{R} \& \mathrm{D}$ is optimized, even though the direct product functions $y=a x_{1}$ which one observes in practice may be subject to constant returns to scale. ${ }^{7}$

The observable productivity coefficient $a$ in $y=a x_{1}$ can be obtained by differentiating equation (iii) with respect to $x$. In economic theory this derivative is called the marginal product of the total inputs $x$, and should approximate the rate of remuneration of those inputs, such as wages and rentals, depending on the exact institutional arrangements of the economy in question. The marginal product of $x-a$ is itself an increasing function of $x$ and thus rises with the size of the economy as $\mathrm{R} \& \mathrm{D}$ is optimally performed. A consistent and purely economic explanation of U.S. technological superiority over its much smaller Latin American neighbors therefore exists: the large size of the U.S. resource base relative to theirs. Size alone raises all factor rewards, as equation (ii) indicates, and thus attracts mobile factors of production (notably skilled and unskilled labor). In answer to the motivating question of this section, this technological superiority is likely to persist for a very long time, barring an extraordinary change in the conditions under which technology is transferred to other countries.

\section{III}

\section{Economic Relations Between Technologically DisParate COUNTRIES}

This section presents a model of two countries that are: 1) mutually open to both international trade and the migration of capital and both skilled and unskilled labor, and 2) subject to tariffs on imports of goods and services and to international transportation costs affecting goods, services, capital equipment, and the two types of labor. The model operates by assuming in different experiments that capital, unskilled labor, and skilled labor are internationally mobile (though

7. Several studies have shown that carefully measured increases in the inputs of capital and labor and changes in their allocation and composition over time fail to explain the corresponding increase in aggregate output. According to E. Denison, The Sources of Growth in the United States 266 (Committee for Economic Development Supp. Paper No. 13, 1962), input growth explained directly only a $2 \%$ rise in aggregate output between 1929 and 1957 when that output rose by $2.93 \%$. Denison explained the residual by advances in knowledge $(0.58)$, scale economies $(0.34)$, and other causes $(0.01)$. The $R \& D$ model herein is perfectly consistent with these findings. It exhibits overall scale economies that make output grow faster than do inputs as it makes endogenous the creation and effects on output of new knowledge, which is treated exogenously by Denison. For a recent account of U.S. technology in comparative and other terms, see Mansfield, Technology and Productivity in the United States, in THE AMERICAN ECONOMY in Transition 563 (M. Feldstein ed. 1980). • 
still subject to transport costs) or, alternatively, are immobile (the transport costs are made prohibitive). Presented also are experiments in which tariffs are lifted and an experiment in which the poor country restricts its formation of skilled workers in an attempt to stem the outflow of resources which their emigration represents.

Testing and examining trade in goods and the migration of labor and of capital as alternatives requires a classification, presented in table 1 , of goods according to their relative input requirements per ton of material outputs for capital, unskilled labor, and skilled labor. Table 2 arranges the numbers representing all unit input requirements in an input-output table. Such tables have been constructed for most countries and are widely used in forecasting and planning. ${ }^{8}$ Unfortunately, no table has been constructed according to the required classification scheme of table 1 and all existing tables are in value terms, rather than in the necessary physical unit.

The immense empirical work that reworking existing tables would require (with uncertain results) can be avoided through a careful consideration of certain physical constraints affecting all production. A ton of anything must contain a ton of matter which ultimately comes from the earth or from land. One category of products, 1-3 in the tables, therefore needs mainly land in addition to inputs of Products 10,11 , and 7 , while a second category, corresponding to the whole spectrum of services and of processed and manufactured goods, requires mainly the material inputs of Products 1-3 in addition to inputs of Products 10,11, and 7. These are the Products 4-6, each ton of which needs about one ton of Products 1-3. Because no reported correlation exists between the capital and labor intensiveness of processed and manufactured goods and that of their material inputs, Products 1,2 , and 3 were each given equal importance as inputs into each of the Products 4 , 5 , and 6 , as can be seen in table 2 .

The unit requirements of Products 1-6 for Products 10,11, and 7 have been chosen to span the maximum area of the relevant input simplexes (the triangles formed in the input space 7,10 , and 11 by constraining all input coefficients to sum to unity) consistent with reasonable usage of all relevant factors and with imparting the same importance to each product within its category. Because the choice of physical units in which to measure inputs of Products 7, 10, and 11 is perfectly arbitrary, the only empirical assumption is that products are symmetri: cally distributed with respect to their relative input requirements.

8. For some applications involving both the United States and various developing countries, see C. Almon, The AMERican Economy to 1975: An INTERIndustry Forecast (1966); Ayres \& Shapanka, Explicit Technological Substitution Forecasts in Long-Range Input-Output Models, 9 TECHN. ForeCASTING \& SOC. Change 113 (1976); Bottomley, Input-Output Studies of Developing Economies, in MEDIUM-TERM DYNAMIC Forecasting 223 (W. Grossling ed. 1977); A. Carter, Structural Change in the American ECONOMY CONTRIBUTION TO INPUT-OUTPUT ANALYSIS (1970); W. LEONTIEF, THE STRUCTURE OF THE United States Economy 1919.39 (1941); U.S. Department of Commerce, The Input-OutPut Structure of The U.S. Economy, 1972 (Nov. 1977); U.S. Department OF Labor, The Structure OF THE U.S. ECONOMY IN 1980 TO 1985 (1975). 
TABLE 1

NOMENCLATURE

\begin{tabular}{cll}
\hline Product No: & & Type or Name of Product: \\
\cline { 1 - 1 } 1 & & Capital-Intensive Land Products \\
2 & & Labor-Intensive Land Products \\
3 & & Skilled Labor-Intensive Land Products \\
4 & & Capital-Intensive Manufactures and Services \\
5 & & Labor-Intensive Manufactures and Services \\
6 & & Skilled Labor-Intensive Manufactures and Services \\
7 & & Skilled Labor \\
8 & & International Transport \\
9 & Land \\
10 & Capital \\
11 & Unskilled Labor \\
\hline
\end{tabular}

Table 2 represents the technology of each of the two countries. Each product is produced by an industry bearing its same number, with the unit output in question being indicated by +1.0 . The remaining (negative) coefficients in each column represent that industry's unit input requirements. In addition to the six products and industries described above, there also exists an industry which produces international transport services (measured in terms of tonnage transported) and an industry which produces skilled labor (measured in natural units). Skilled labor, considered as a product, is obviously intensive in unskilled labor, the subject of the training, while transport services are considered neutral with respect to their input requirements.

The technological superiority of Country 2 is modelled by making its unit input requirements of Products 7,9,10, and 11 substantially lower than the corresponding coefficients of Country 1 , as shown in table 2. While there is no indisputable way to determine superiority empirically at this level of aggregation of actual countries and products, in view of the vast income disparity between the United States and most Latin American countries, the assumption of a universal 4-to-1 U.S. productivity advantage is highly conservative. Increasing the productivity advantage would preserve and accentuate all of the qualitative conclusions. On the other hand, the implicit assumption in table 2 that technological disparity is unrelated to factor usage is possibly untrue; here, too, empirical studies are lacking. Finally, each industry's input and output coefficients in table 2 are taken to be invariant with respect to its level of operation (constant returns to scale) or to that of any other industry or set of industries (no external economies or diseconomies).

On the demand side of the economy, each individual member of each country has a utility function of the exponential form

$$
u=d_{1}{ }^{e} d_{2}^{e_{2}} \ldots d_{n}^{e n}
$$

where $d_{k}$ is the amount that he consumes of the $k$ th product, where the exponent $e_{k}$. expresses its relative importance, and where $e_{1}+e_{2}+\ldots+e_{n}=1$. The assumption that everyone shares this basic utility function means that it applies indifferently to social groups, classes, countries, and the world community, regardless of 
TABLE 2

\section{TECHNOLOGY}

Country 1's Technology:

\begin{tabular}{|c|c|c|c|c|c|c|c|c|}
\hline \multirow{2}{*}{\multicolumn{2}{|c|}{$\begin{array}{l}\text { Activities: } \\
\text { Inputs/Outputs: }\end{array}$}} & \multirow{2}{*}{ (2) } & \multirow[t]{2}{*}{ (3) } & \multirow[t]{2}{*}{ (4) } & \multirow[t]{2}{*}{ (5) } & \multirow[t]{2}{*}{ (6) } & \multirow[t]{2}{*}{$(7)$} & \\
\hline & & & & & & & & \\
\hline 1 & 1.0000 & 0.0 & 0.0 & -0.3000 & -0.3000 & -0.3000 & -0.0100 & -0.2000 \\
\hline 2 & 0.0 & 1.0000 & 0.0 & -0.3000 & -0.3000 & -0.3000 & -0.0100 & -0.2000 \\
\hline 3 & 0.0 & 0.0 & 1.0000 & -0.3000 & -0.3000 & -0.3000 & -0.0100 & -0.2000 \\
\hline 4 & -0.0010 & -0.0010 & -0.0010 & 1.0000 & -0.0100 & -0.0100 & -0.0100 & -0.0100 \\
\hline 5 & -0.0010 & -0.0010 & -0.0010 & -0.0100 & 1.0000 & -0.0100 & -0.0100 & -0.0100 \\
\hline 6 & -0.0010 & -0.0010 & -0.0010 & -0.0100 & -0.1000 & 1.0000 & -0.0100 & -0.0100 \\
\hline 7 & -0.1000 & -0.1000 & -1.0000 & -0.1000 & -0.1000 & -1.0000 & 1.0000 & -0.4000 \\
\hline 8 & 0.0 & 0.0 & 0.0 & 0.0 & 0.0 & 0.0 & 0.0 & 1.0000 \\
\hline 9 & -1.0000 & -1.0000 & -1.0000 & 0.0 & 0.0 & 0.0 & -0.1000 & -0.1000 \\
\hline 10 & -1.0000 & -0.2000 & -0.2000 & -1.0000 & -0.2000 & -0.2000 & -1.0000 & -0.5000 \\
\hline 11 & -0.2000 & -1.0000 & 0.0 & -0.2000 & -1.0000 & 0.0 & -1.5000 & -0.5000 \\
\hline \multicolumn{9}{|c|}{ Country 2's Technology: } \\
\hline Activities: & (1) & (2) & (3) & (4) & (5) & (6) & (7) & (8) \\
\hline \multicolumn{9}{|c|}{ Inputs/Outputs: } \\
\hline 1 & 1.0000 & 0.0 & 0.0 & -0.3000 & -0.3000 & -0.3000 & -0.0100 & -0.2000 \\
\hline 2 & 0.0 & 1.0000 & 0.0 & -0.3000 & -0.3000 & -0.3000 & -0.0100 & -0.2000 \\
\hline 3 & 0.0 & 0.0 & 1.0000 & -0.3000 & -0.3000 & -0.3000 & -0.0100 & -0.2000 \\
\hline 4 & -0.0010 & -0.0010 & -0.0010 & 1.0000 & -0.0100 & -0.0100 & -0.0100 & $-0: 0100$ \\
\hline 5 & -0.0010 & -0.0010 & -0.0010 & -0.0100 & 1.0000 & -0.0100 & $-0.0100^{\circ}$ & -0.0100 \\
\hline 6 & -0.0010 & -0.0010 & -0.0010 & -0.0100 & -0.0100 & 1.0000 & -0.0100 & -0.0100 \\
\hline 7 & -0.0250 & -0.0250 & -0.2500 & -0.0250 & -0.2500 & -0.2500 & 1.0000 & -0.1000 \\
\hline 8 & 0.0 & 0.0 & 0.0 & 0.0 & 0.0 & 0.0 & 0.0 & 1.0000 \\
\hline 9 & -0.2500 & -0.2500 & -0.2500 & 0.0 & 0.0 & 0.0 & -0.0025 & -0.0025 \\
\hline 10 & -0.2500 & -0.0500 & -0.0500 & -0.2500 & -0.0500 & -0.0500 & -0.2500 & -0.1250 \\
\hline 11 & -0.0500 & -0.2500 & 0.0 & -0.0500 & -0.2500 & 0.0 & -1.0125 & -0.1250 \\
\hline
\end{tabular}

the distribution of income among the individual members in question. ${ }^{9}$ This is a reasonable assumption because end products are defined here in terms of direct and indirect factor content and not in terms of purpose, materials, or attributes. It asserts only that everyone has identical tastes for the factor services embodied in end products, not for those goods themselves. This makes it possible to consider the dependent variable $u$ as a cardinal measure of economic wellbeing or, in other words, of the real income of a group (such as unskilled labor), of a country, or of a set of trading partners. The term "utils" is often used in economics to name the units for measuring $u$ and will be adopted here.

The exponential utility function has other certain convenient properties. If the consumer maximizes his utility. level as expressed by this function (subject to his income constraint), the share of his income that he spends for a given product will

9. For a discussion of the problems involved in aggregating individual preferences to obtain social preference and demand functions, see Chipman \& Moore, On Social Welfare Functions and the Aggregation of Preferences, J. ECON. THEORY 111 (1979). 
be equal to its exponent. Thus, his demand $d_{k}$ for the $k$ th product will be equal to $e_{k} r / p_{k}$, where $r$ is his money income and $p_{k}$ is the price that he faces for the $k$ th product. This relationship determines in the various experiments the amount of each product that will be demanded in each country as a function only of that country's money income and its list of prices, given the constant expenditure shares reported in table 3 .

\section{TABLE 3}

EXPENDITURE SHARES

\begin{tabular}{|c|c|c|}
\hline Product & In Country 1 & In Country 2 \\
\hline 1 & $\ldots .0 .04$ & 0.04 \\
\hline 2 & $\ldots .0 .04$ & 0.04 \\
\hline 3 & $\ldots \ldots .04$ & 0.04 \\
\hline 4 & $\ldots .0 .30$ & 0.30 \\
\hline 5 & $\ldots .0 .28$ & 0.28 \\
\hline 6 & $\ldots .0 .30$ & 0.30 \\
\hline 7 & $\ldots .0 .00$ & 0.00 \\
\hline $8 \ldots$ & $\ldots 0.00$ & 0.00 \\
\hline
\end{tabular}

Table 4 lists the assumed endowments of goods, services, and primary factors for the two countries in the model. No initial supplies of products are assumed, but only primary factors. In particular, all skilled labor is produced within the production period assumed for the long term analysis. Observe that Country 1 has a large supply of unskilled labor relative to its supplies of land and capital (as compared with Country 2) and that each country owns some factors located in the other. The United States (Country 2) thus has some land and capital in Country 1 , while some of Country 1's unskilled workers are located in Country 2. The income of all of a country's factors, whether they work at home or abroad, is credited to its national income in this model.

TABLE 4

\section{Primary FaCtOR ENDOWMENTS}

\begin{tabular}{|c|c|c|c|c|}
\hline \multirow[b]{2}{*}{ Factor } & \multicolumn{2}{|c|}{ Of Country 1} & \multicolumn{2}{|c|}{ Of Country 2} \\
\hline & At Home & Abroad & At Home & Abroad \\
\hline 9 & . . 38.00 & 0.00 & 100.00 & 2.00 \\
\hline 10 & $\ldots 40.00$ & 0.00 & 115.00 & 5.00 \\
\hline 11. & $\ldots 155.55$ & 5.00 & 120.00 & 0.00 \\
\hline
\end{tabular}

Table 5 lists the ad valorem tariff rates which apply currently to international trade between Latin America and the United States. The tariffs of Country 1 are particularly high for manufactured goods, in categories 4 through 6 , in accordance with the import-substituting policies of Latin American countries. The American 
tariffs discriminate against imports which are intensive in the services of unskilled labor. ${ }^{10}$

TABLE 5

Percentage Ad Valorem Import Duties

\begin{tabular}{|c|c|c|}
\hline Product & Of Country 1 & Of Country 2 \\
\hline 1 & 7.00 & 1.00 \\
\hline 2 & 5.00 & 10.00 \\
\hline 3 & 12.00 & 1.00 \\
\hline 4 & 25.00 & 0.00 \\
\hline 5 & 20.00 & 12.00 \\
\hline 6 & 25.00 & 10.00 \\
\hline 7 & 0.00 & 0.00 \\
\hline 8 & 5.00 & 6.00 \\
\hline
\end{tabular}

The importation of any product requires transport services, i.e., Product 8 . Those services may be provided locally or may themselves be imported. The assumptions regarding unit transport costs will be listed separately for each experiment performed with the model, because the different policies restricting migration and capital imports will be represented as if they were prohibitive unit transport requirements, equal to 99.00 of Product 8 per unit imports of the factor service in question.

Each policy experiment is a run of the model using the above numbers. Solutions must all possess the following properties: 1) each country's demand for each product is equal to its net availabilities of that product whenever its price exceeds zero, 2) all prices must be non-negative, and 3) the unit profits net of taxes of any operating industry or importing activity must be equal to zero and less than zero otherwise. The four experiments made in this section all assume that Country 2 is technologically superior to Country 1 as shown by the primary input coefficients in table 2. Each experiment title bears a policy number for comparing its results with those of several others as depicted in table 7.

Experiment A posits the existing situation-namely, that some illegal unskilled labor immigration to the United States has already taken place (five units of Country 1's labor work in Country 2); that skilled labor, once it is formed in either country, is free to emigrate to the other; and that no other factor of production is free to move from one country to the other. These mobility assumptions are reported in the first two columns of the first table of experiment $A$. The columns labelled "Gross Domestic Production" in that table report the levels at which the various activities of table 2 operate. The net availabilities of products that are reported are equal to the gross domestic outputs plus imports (also reported) minus domestic intermediate usage (which is not reported). The final two columns in the table report the prices of goods (Items 1 through 8) and factor services (Items 9 through 11). The second table in the experiment reports the national income of each country in terms of the international monetary unit and also in real terms

10. See supra note 1. 


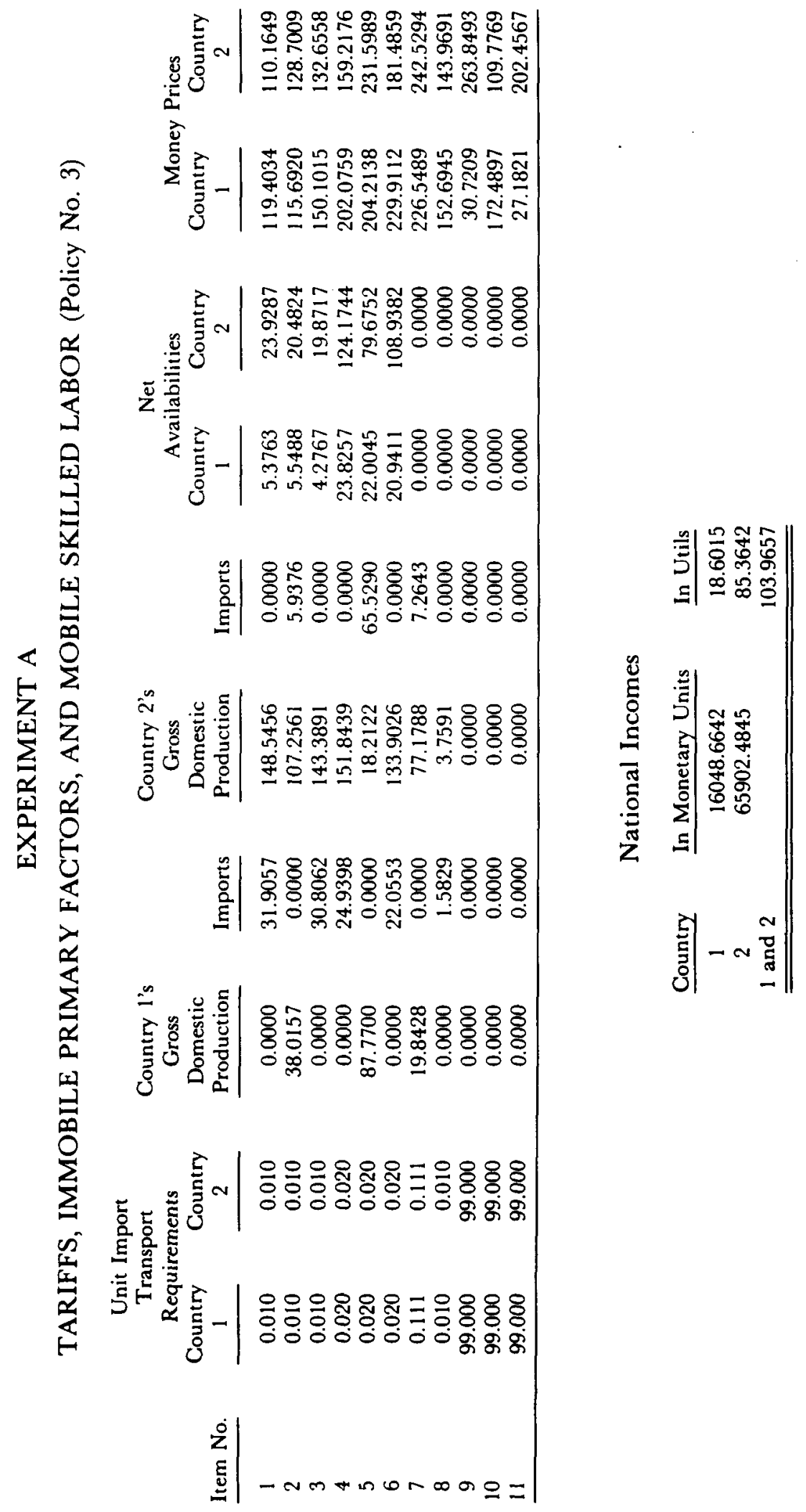


(as utils calculated by the exponential formula explained above), using the expenditure shares reported in table 3 and the net availabilities as reported in the first table of the experiment. World real income is the sum of the national levels. All seven experiments in this paper will be presented in the same way as is experiment A.

Country 2 imports 7.2643 units of skilled labor in experiment A, an amount equal to about one-third of Country 1's production of 19.8428 units of skilled labor. Unskilled labor fetches 27.1821 monetary units per unit in Country 1 , as compared with 202.4567 units in Country 2. Skilled wage rates, however, are comparable in the two countries in view of the freedom of skilled labor to migrate and the moderate international transportation costs that apply. This freedom creates a large earnings disparity between the two types of labor within Country 1.

While the money wage differential in this experiment is certainly large enough to induce unskilled labor to migrate to Country 2, the best measure of that inducement is the disparity in real wages. A country's real wage rate can be computed by multiplying its money wage rate by its real national income, as expressed in utils, and dividing the result by the country's national income in monetary units. " The calculation (27.1821 times 18.6015 divided by 16048.6642 ) yields 0.031506 as Country l's real unskilled wage rate in utils. The corresponding rate in Country 2 by the same calculation is 0.262244 utils.

The injustice to unskilled workers in Country 1 who cannot avail themselves of educational opportunities is obvious in experiment A. Experiment B examines, therefore, what would happen if Country 2 should apply the same restrictions to skilled labor immigration as it applies to the unskilled, and lists the corresponding transport-cost assumptions and the results of the new calculation. The real income of Country 1 rises from 18.6015 utils to 20.4564 utils, and the unskilled money wage rate increases to 83.0901 units. The real unskilled wage rate in Country 1 rises to 0.078414 utils per unit, and in Country 2 to 0.299472 utils. The unskilled wage rate more than doubles in Country 1 when skilled labor migration is stopped and, surprisingly, rises in Country 2 as well. Country 2 now imports more unskilled labor-intensive products from Country 1 and its real income declines somewhat. World real income remains almost exactly the same.

Although Country 1's unskilled workers benefit from Country 2's restriction of skilled labor migration, the only way of effectuating an equivalent policy would probably be to change the political regime of Country 1 and to prohibit skilled worker emigration, as did East Germany and Cuba. A nearly equivalent policy, however, would be for Country 1 to reduce the national output of skilled workers.

11. One of the disturbing recent changes in the U.S. economy is the decline in the rates of growth of the real wage rate of labor productivity since about 1968. Freeman, The Evaluation of the American Labor Market, 1948-80, in The AMERICAN Economy in Transition 351 (M. Feldstein ed. 1980), documents this decrease and reports that its causes remain mysterious. Surely however, immigration and liberalized foreign investment and trade (which Freeman does not mention) have depressed the unskilled wage rate just as our models in this paper indicate would happen under those circumstances. As it has in the past, the continued failure of real wages to rise and their eventual possible decline will undoubtedly raise domestic political awareness of the relationship between foreign economic policy and the distributions of the national income. 


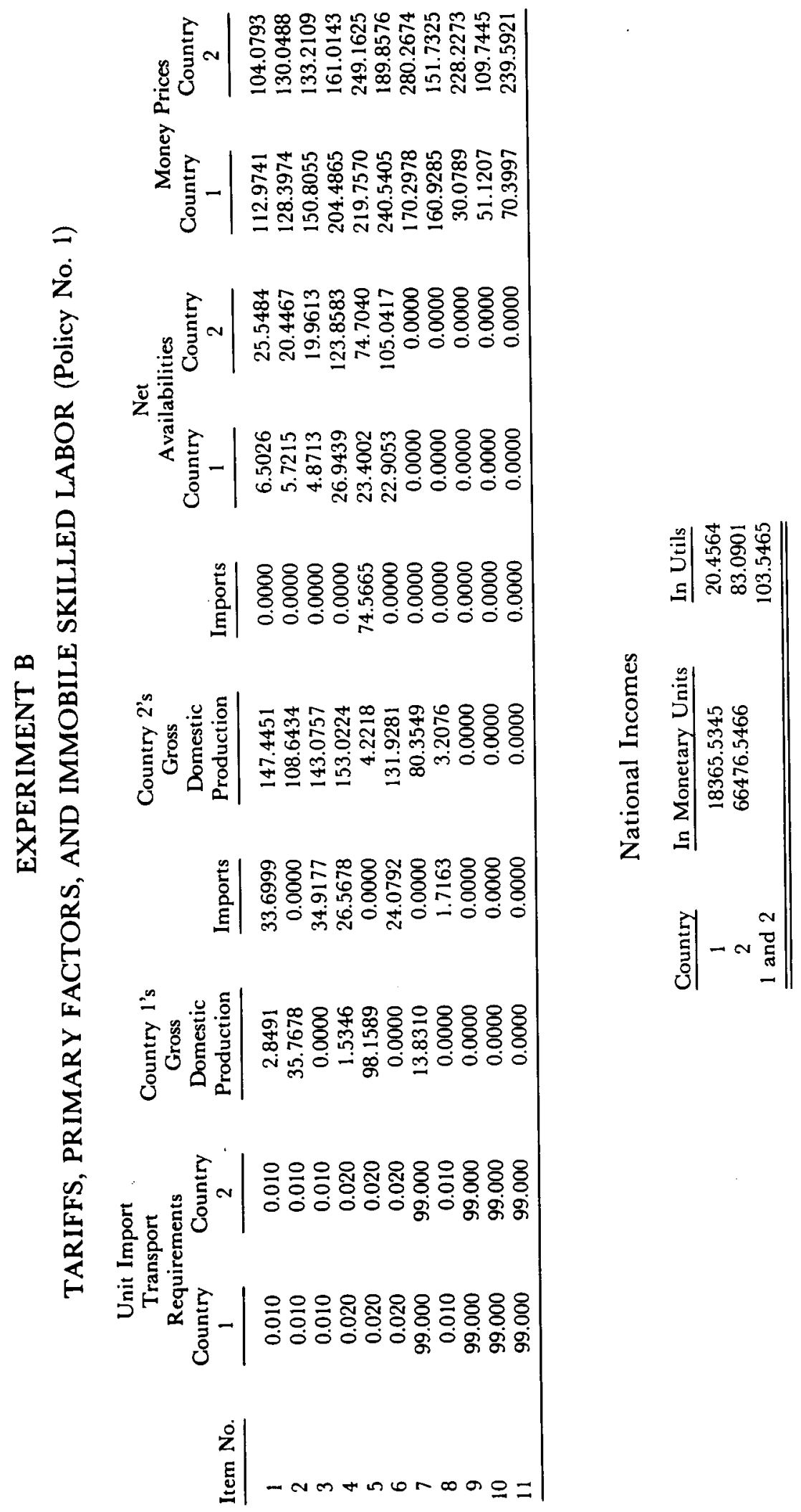



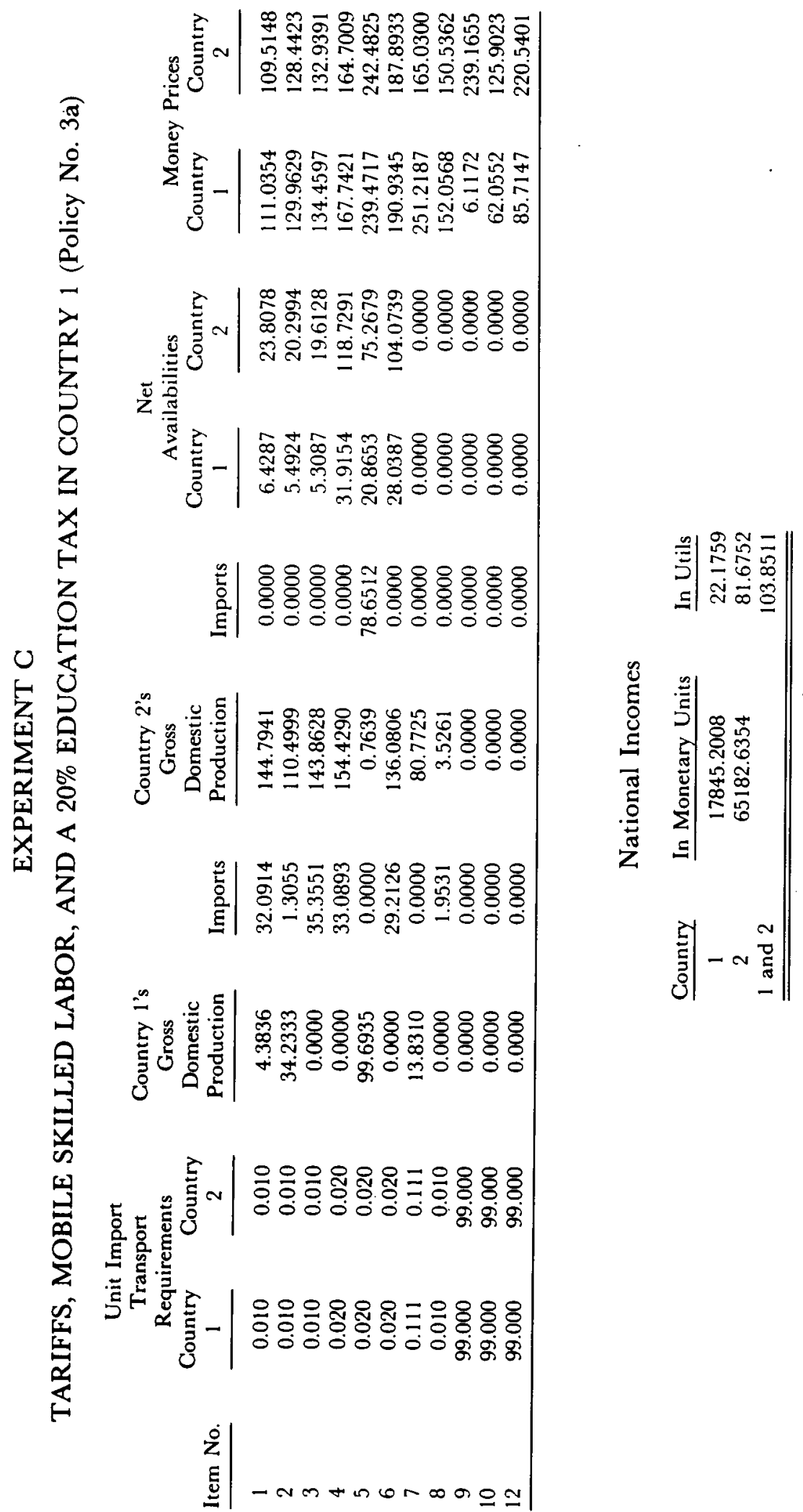
To simulate this policy, the model subjects Activity 7 in Country 1 to an ad valorem tax on its output, skilled labor. Experiments with this tax rate indicate that Country 1's real national income reaches a maximum of 22.1904 utils when the rate is set at $0.30(30 \%)$, and that the real unskilled wage rate in Country 1 reaches a maximum of 0.106516 utils per unit when the tax rate is 0.20 . This rate was accordingly chosen for experiment $\mathrm{C}$, which otherwise reverts to the mobility assumptions of experiment $A$. Experiment $C$ raises the real unskilled wage rate in Country 2 to 0.270341 utils per unit, which is slightly higher than that rate under experiment $A$. For easy comparison, the real national incomes and unskilled wage rates of the two countries are reported in table 7 for twenty-two different policy experiments as described in table 6. Experiment $\mathrm{C}$ (policy $3 \mathrm{a}$ in table 7) yields very nearly the highest unskilled wage rate for Country 1 of all the policies.

It is ironic that the retrograde policy of taxing education (or failing to subsidize it optimally) in Country 1 is nonetheless highly beneficial to those of its workers who are unable to avail themselves of educational opportunities provided at public expense. Indeed, the unskilled real wage rate more than triples as compared to its level in experiment A (policy 3 in table 7). Unskilled workers certainly form a majority in the typical country belonging to our Country 1 category. Under a fair democratic regime they would rationally vote to remain in a position of international intellectual inferiority. The formation of a national trained elite, on the other hand, would imply some degree of authoritarianism.

Experiment $D$ now asks what would happen if, when Country 1 removes its education tax in experiment $\mathrm{C}$, the countries then permitted the free international migration of both skilled and unskilled labor while still prohibiting the migration of capital. (Tables 6 and 7 omit this policy.) Country 2's import column reveals that it no longer imports any skilled workers from Country 1 (although that migration is free), but instead receives 66.3644 unskilled workers-equal to $42 \%$ of Country l's work force. This vast migration depresses the unskilled wage rate in Country 2 to the level that just covers international transport costs, which means that the unskilled wage rate falls to zero in Country 1. Country 2's real income increases considerably, while that of Country 1 declines drastically.

The surprising results of experiment $D$ confirm one's visceral feeling that unfettered migration of unskilled labor to the United States would be a disaster, however unjust the restrictions. The next section looks for available policies that can resolve this fundamental dilemma of immigration policy.

\section{IV}

\section{INDIRECT APPROACHES TO THE IMMIGRATION PROBLEM}

The surprises which the general equilibrium study of migration has revealed in the preceding section motivate a systematic search of the full range of available foreign and domestic economic policy instruments bearing on migration incentives. For example, eliminating tariffs should remove some of the pressure for the migration of unskilled workers. The lack of the best technology may hamper this 

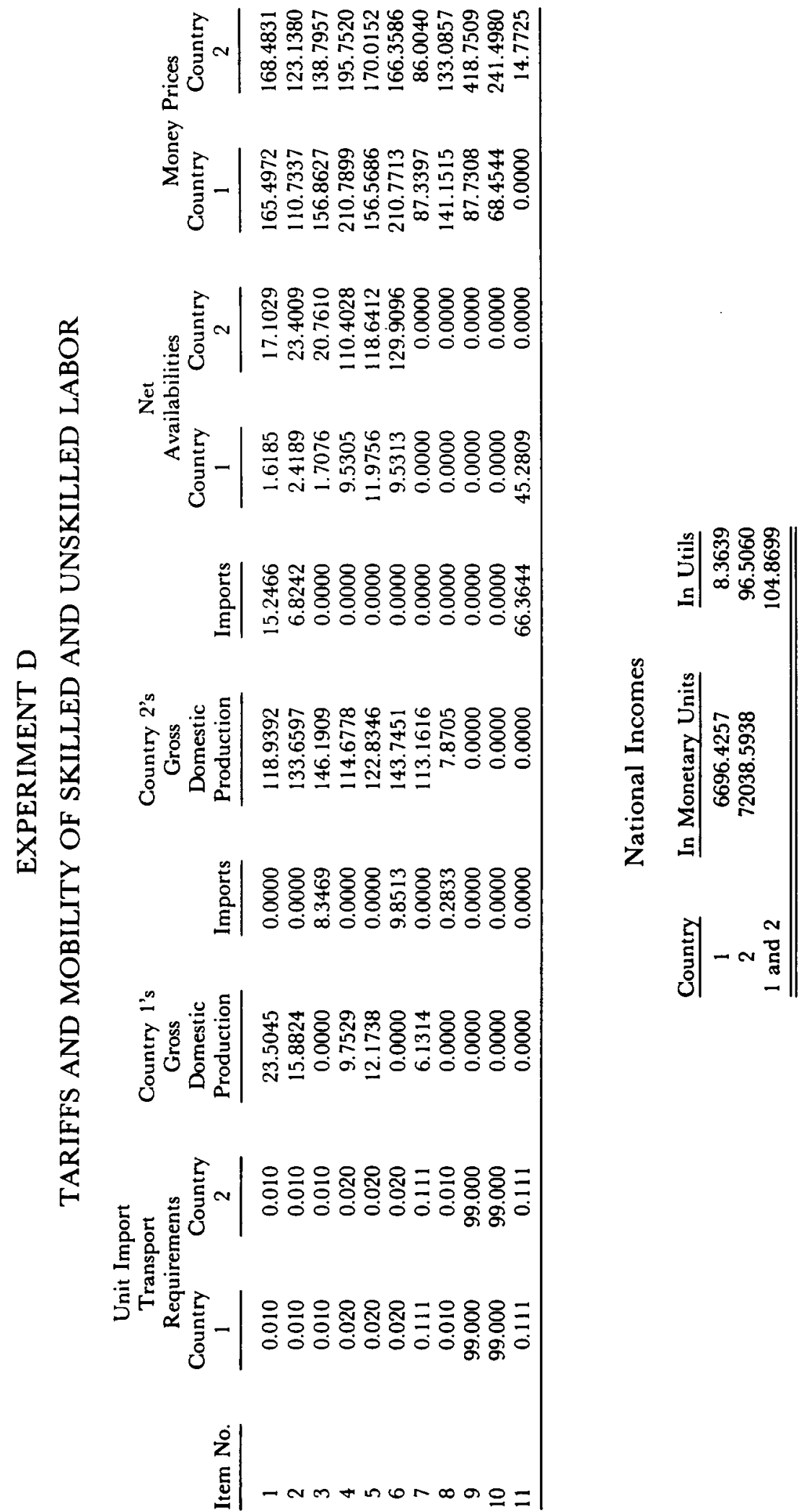
policy, however, and so the effects of transferring U.S. technology to countries of emigration must also be examined. Although it is widely believed that the transfer of U.S. technology damages its competitive position and presumably, therefore, damages U.S. real income, ${ }^{12}$ the United States would actually benefit from the transfer of its technology. The American income distribution, however, would be severely altered.

Table 6 is a list of twenty comprehensive policy combinations affecting migration, income distribution, and national income. The tariffs which apply are those listed in table 5. Technology transfer means that both countries enjoy Country 2's technology, as listed in table 2.

TABLE 6

Policies

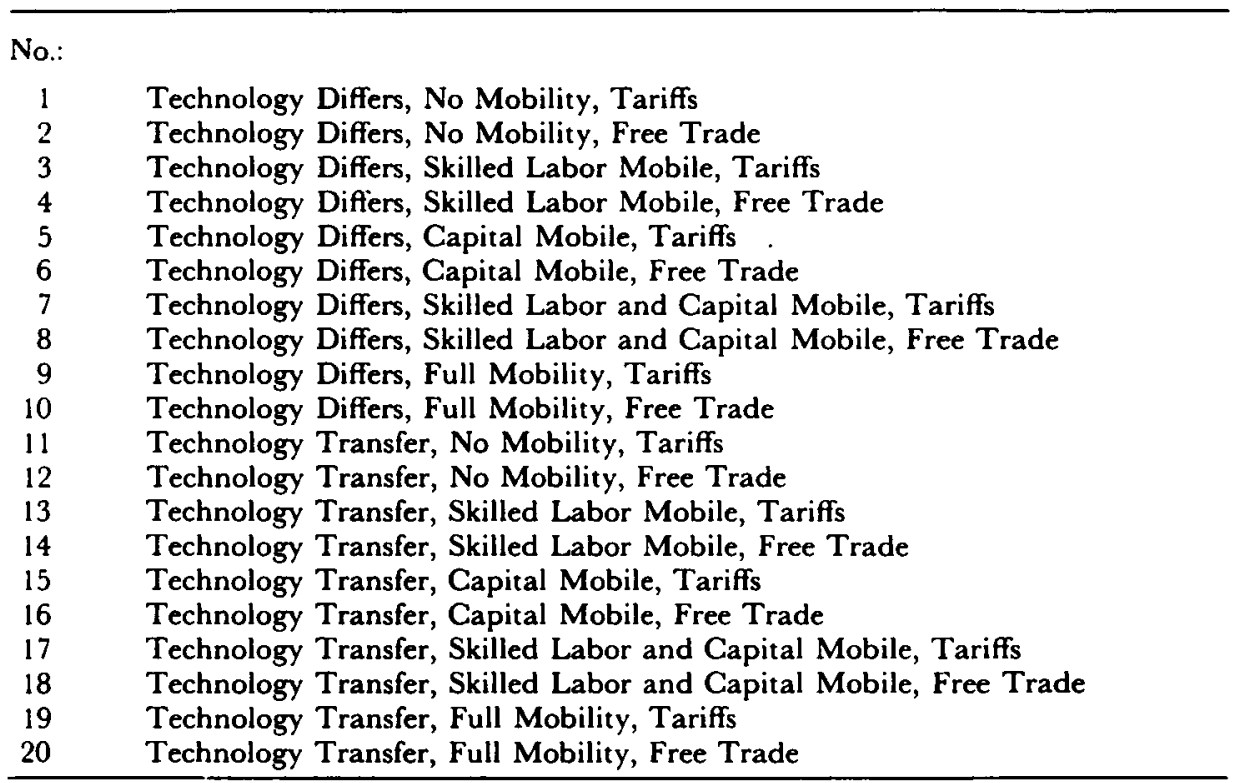

Table 7 summarizes the results of the twenty policies listed in table 6 , plus the subpolicies $3 \mathrm{a}$ and $4 \mathrm{a}$ in which Country 1 performs the educational experiment already reported. Policy $3 a$ is experiment C. In policy $4 a$, Country 1 further restricts the formation of skilled labor, as if it were now subject to a $30 \%$ rather than only a $20 \%$ tax. This policy yields the highest level of Country 1's real national income of all policies in which technology remains disparate. Table 7 presents the real unskilled wage rate in each country as a function of the policy adopted and also of each country's real income. Real wage rates are calculated as before, by multiplying the ratio of the money wage rate to the money national income of the country by its level of real income.

12. See, e.g., Branson, supra note 6, at 186. 
TABLE 7

Selected Results of Twenty Basic Policies

\begin{tabular}{|c|c|c|c|c|c|}
\hline \multirow[t]{2}{*}{ No. } & \multicolumn{2}{|c|}{ Unskilled Labor's Real Wage } & \multicolumn{3}{|c|}{ (Real Income In) } \\
\hline & Country 1 & Country 2 & Country 1 & Country 2 & World \\
\hline 1 & .078414 & 299472 & 20.4564 & 83.0901 & 103.5465 \\
\hline 2 & .110821 & .276338 & 22.1542 & 81.6971 & 103.8513 \\
\hline 3 & .031506 & .262244 & 18.6015 & 85.3642 & 103.9657 \\
\hline $3 a$ & .106516 & .270341 & 22.1759 & 81.6752 & 103.8511 \\
\hline 4 & .084034 & .245416 & 20.6444 & 83.5109 & 104.1553 \\
\hline $4 a$ & .103653 & .276344 & 22.1904 & 81.6606 & 103.8510 \\
\hline 5 & .045414 & 297715 & 20.1849 & 83.5713 & 103.7562 \\
\hline 6 & .109789 & .280115 & 22.1526 & 81.8121 & 103.9647 \\
\hline 7 & .030211 & 239638 & 17.7149 & 86.1032 & 103.8180 \\
\hline 8 & .084702 & .251932 & 20.9119 & 83.2508 & 104.1627 \\
\hline 9 & .00 & .017910 & 8.0236 & 96.9317 & 104.9554 \\
\hline 10 & .006987 & .024870 & 9.8886 & 96.3848 & 106.2734 \\
\hline 11 & .00 & .00 & 36.0015 & 100.8585 & 136.8599 \\
\hline 12 & .00 & .00 & 37.0260 & 99.9573 & 136.9834 \\
\hline 13 & .00 & .00 & 36.0015 & 100.8585 & 136.8599 \\
\hline 14 & .00 & .00 & 37.0260 & 99.9573 & 136.9834 \\
\hline 15 & .00 & .00 & 36.0015 & 100.8585 & 136.8599 \\
\hline 16 & .00 & .00 & 37.0260 & 99.9573 & 136.9834 \\
\hline 17 & .00 & .00 & 36.0015 & 100.8585 & 136.8599 \\
\hline 18 & .00 & .00 & 37.0260 & 99.9573 & 136.9834 \\
\hline 19 & .00 & .00 & 36.0015 & 100.8585 & 136.8599 \\
\hline 20 & .00 & .00 & 37.0260 & 99.9573 & 136.9834 \\
\hline
\end{tabular}

Experiments E, F, and $\mathrm{G}$ have been selected as further illustration of the key policies revealed through table 7. Experiment $E$ illustrates policy 2 and indicates the result when free trade is substituted for the mobility of skilled labor, capital, and unskilled labor. Table 7 reveals that this policy yields the highest real wage rate in Country 1 of all the policies and also the highest ratio of Country 1's real wage rate to that of Country 2. Presumably, this is the policy in table 7 which most reduces the incentive for unskilled labor to migrate to Country 2, so long as technology is not transferred.

Experiment $\mathrm{F}$ illustrates policy 10 which, of all the technological disparity policies, yields the highest joint income in the two countries. This policy permits full freedom of trade in goods, capital, and human services but no technology transfer, and is therefore the most liberal of the first ten policies.

Experiment $\mathrm{F}$ also demonstrates that the technologically superior country tends to draw in all the mobile factors of production. ${ }^{13}$ Country 2's table of activity levels in experiment $F$ indicates that it should import both capital services and the services of unskilled labor. Country 1 and its unskilled workers fare badly under this liberal policy while Country 2, apart from its unskilled workers, fares

13. See supra text accompanying note 6 . 


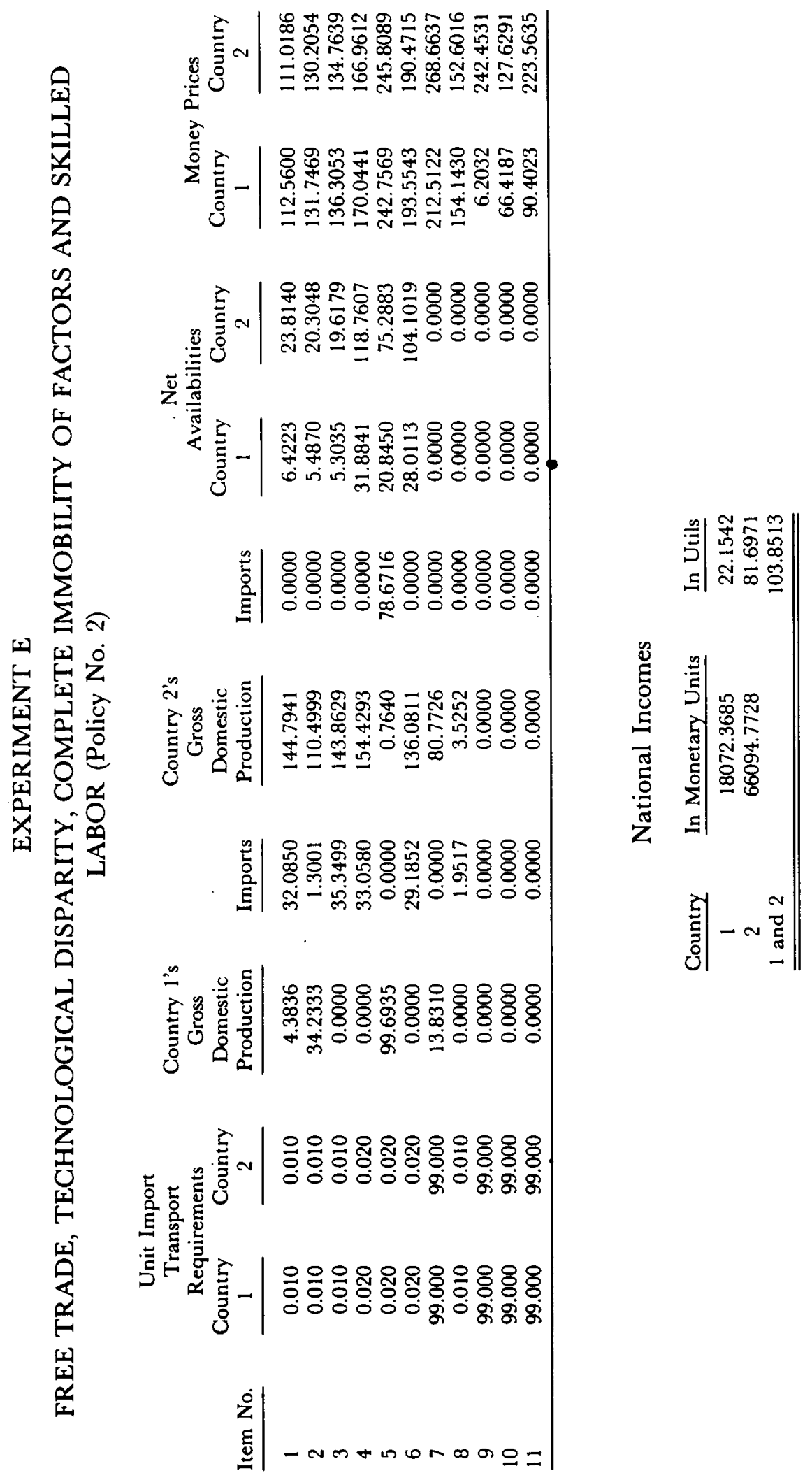




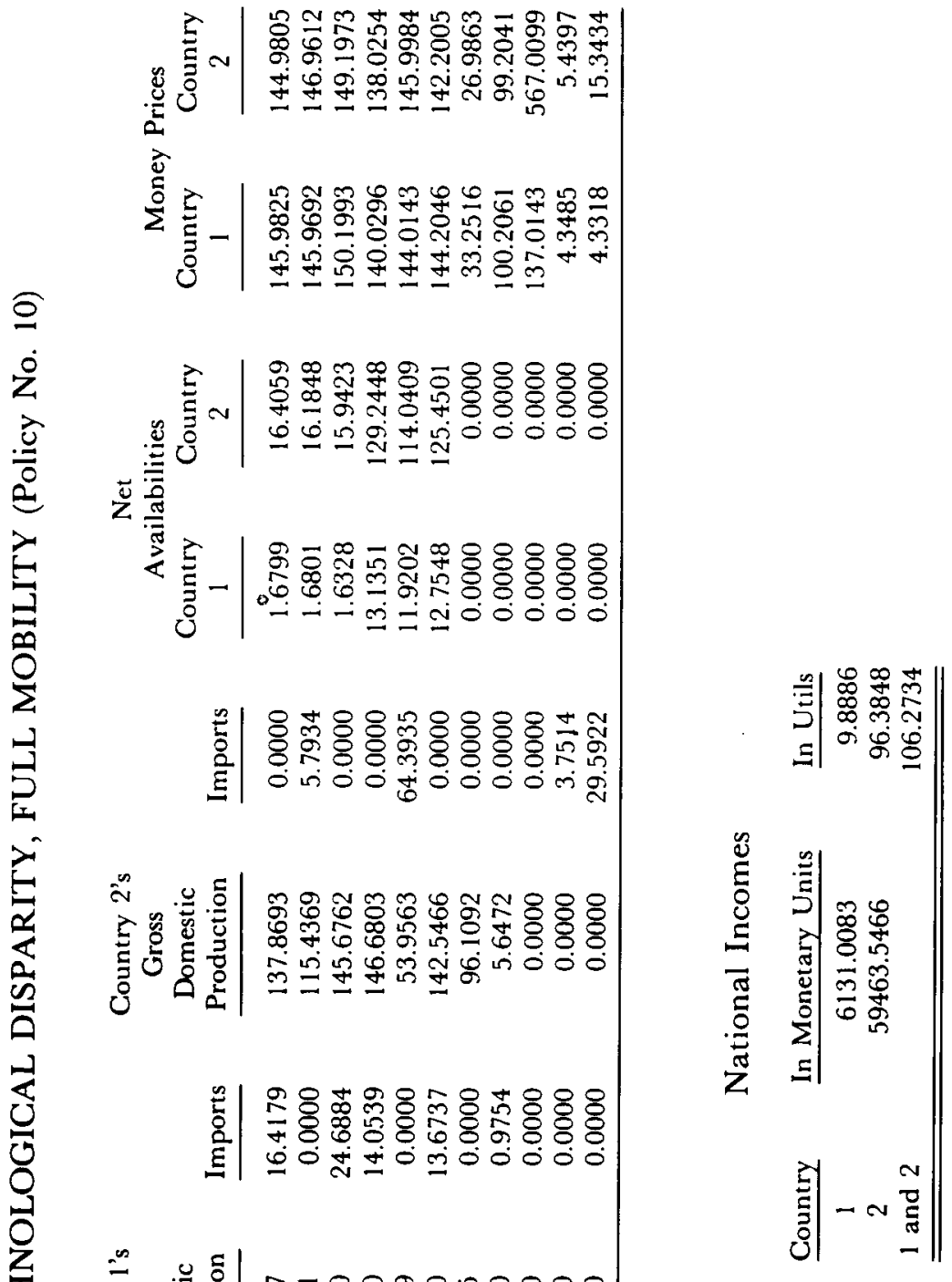

으 

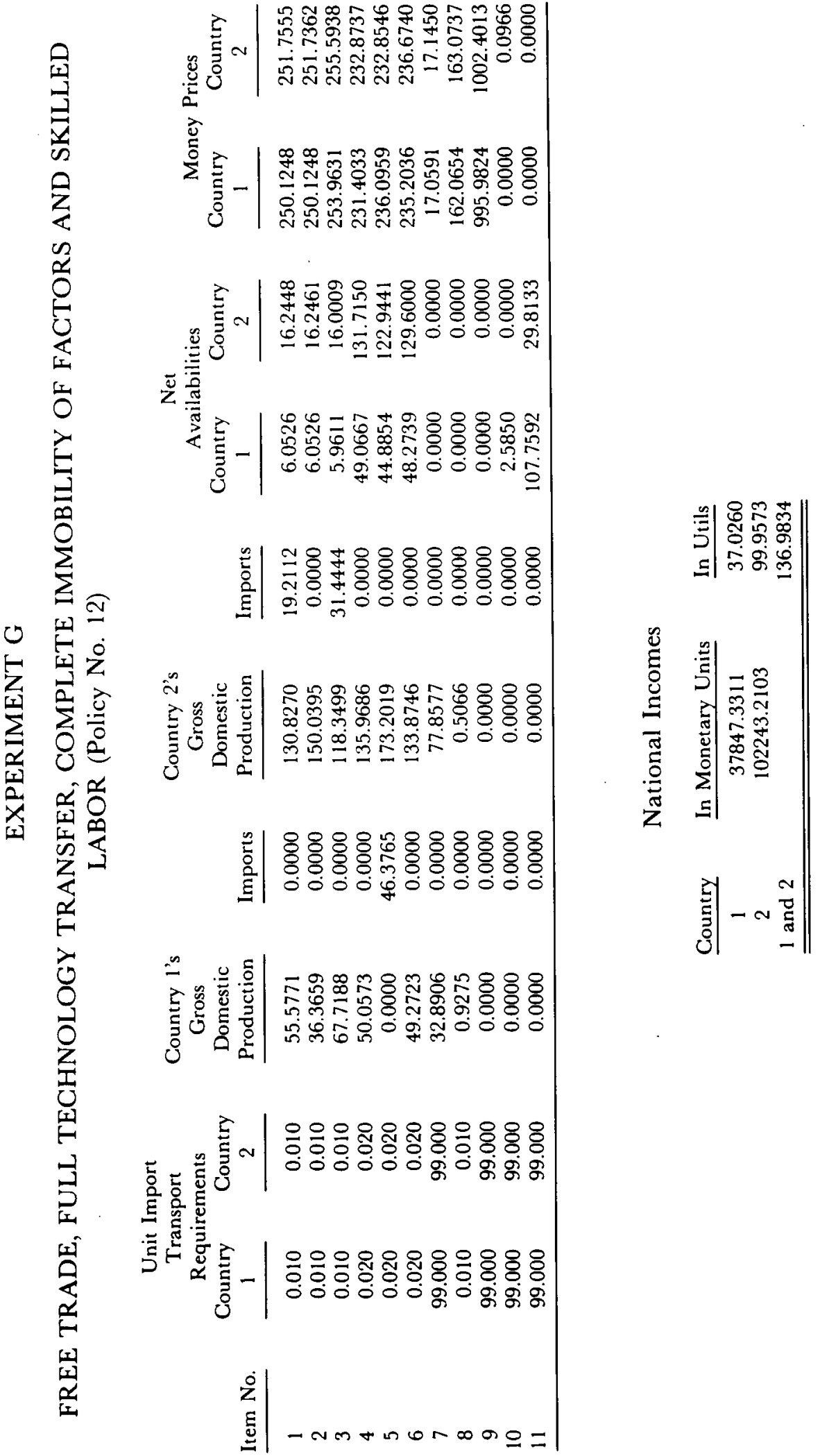
very well. Policies 4 and 8 provide comparable results since the freedom of capital to migrate makes little difference under technological disparity. ${ }^{14}$

None of the first ten policies listed in table 7 either significantly raises Country 1's income or greatly reduces the gap between the wage rates of the two countries. The next task therefore is to see if an effective transfer of technology to Country 1 would alter those objectives.

The answer is "yes," but that raises another problem: the wage rates equalize at zero (and the profit rates very nearly do so) as capital and unskilled labor both become free goods in Country 1 and unskilled labor becomes so in Country 2 as well. Experiment $G$ shows that in that case land alone captures all income in Country 1 and very nearly all in Country 2. Because only land supplies effectively limit output now, restrictions on the migration of capital and labor become nugatory, as policies 11-20 in table 7 show. Tariffs also make little difference in this single-technology and (nearly) single-factor world.

Experiment $G$ nonetheless reveals that technology transfer can raise the incomes of poor countries. Technology transfer is certainly more powerful in this respect than any of the other elements (commodity buffer stocks, price supports for primary products, tariff preferences, increased economic aid, and debt forgiveness) for favoring developing countries in the New International Economic Order (a UN discussion forum). Unlike those other policies, technology transfer creates new income in the developing countries, as opposed to merely transferring it there from developed countries.

\section{Conclusions}

Present U.S. immigration policies permit liberal entry of highly skilled workers and ban, but largely condone, entry of unskilled workers. The U.S.-Mexican border is barely patrolled, identification papers for employment are easily counterfeited, and penalties are derisory. The result is a large and growing illegal work force, consisting mainly of isolated prime-age males subject to unsavory working and living conditions and to various types of exploitation and extortion. This de facto immigration policy threatens to deteriorate the social, economic, and political equilibrium of this country and of Mexico and the other important emigration countries as well. Much more open discussion of this issue is needed, as is a clear

14. Policy 10 (experiment E) proves that what the French economist Arghiri Emmanuel calls "unequal trade" is a distinct possibility. He claims that capital migration from rich to poor countries lowers the earnings of the latter. Experiment $\mathrm{E}$ (or D) shows that worker migration from the poor to the rich country does the same thing. Direct foreign investment by Country 2 in Country 1 to produce goods with 1's labor for 2's market is, of course, equivalent to the emigration of those same workers to 2 and so Emmanuel was right: liberalized foreign investment can damage a country. Unfortunately he was right for the wrong reasons. Paul Samuelson and Pascal Salin have demolished his model and analysis but have wrongly denied the possibility of unequal trade. See A. EMmanuel, L'Echange Inégal, Un EsSaI SUR Les ANTAGONISMES DANS LES RAPPORTS INTERnATIONAUX (2d ed. 1972). This book was translated as Unequal Exchange: A STUdy OF THE IMPerialism of Trade (1972). See also Samuelson, Illogisme de la Doctrine Neo-marxienne de l'Echange Inégal, 17 COMMENT AIRE 52-62 (1982) and Salin, Echange Inégal et Illusion Scientifique, 17 CoMMENTAIRE 63-71 (1982). 
objective picture of the available alternative courses of action. The effects of immigration policies are irreversible and so fundamental that little direct experimentation is possible; experiments must be performed on model economies, as in this paper. If the models are sufficiently realistic, it should be possible to identify the best (or at least a good) set of policies and to build a broad consensus in its favor before implementation. The immigration problem is much deeper than expected. It touches the sensitive roots of income distribution, on which consensus is never directly possible. In this concluding section the discussion will center on the relevance of the model employed, the main conclusions drawn from its manipulation, and some possible ways of accommodating the inevitable shifts in income distribution which must accompany any effective policy.

The relevance and novelty of the fairly large model employed here lies first in its distinction between skilled labor (which is a product requiring primary and intermediate inputs for its manufacture) and the primary inputs of capital, land, and unskilled labor. In this respect, the model goes well beyond the usual twofactor versions of international economic theory and permits us to study education, technology, and relative factor supplies as determinants of migration. Secondly, the model permits a full examination of the role of technological disparities which are at the heart of the migration problem, and of technology transfers to overcome them. Finally, the model easily incorporates the main forms of government intervention in the economy: tariffs, taxes on inputs and outputs, and quantitative restrictions on international movements of capital equipment and of skilled and unskilled labor.

Experiments with selected combinations of such interventions revealed that all of the model's features are essential to the study of migration problems and that immigration policy cannot be separated from a comprehensive international economic policy. The precise aim of such a policy should be to achieve a high degree of effective international economic integration without suffering the highly distorting and permanent side effects of migration. Changes in tariffs, educational policy, and the allocation of technology all have large effects on the real incomes both of countries and of their various factor suppliers. Thus, they all affect the incentive to migrate.

Obviously, an even larger computable general equilibrium model would be better, although probably not in proportion to its size. Computational and especially expositional difficulties mount rapidly with size and so considerable thought was invested in discovering the smallest adequate model. Only time and cost preclude a much larger model, one recognizing perhaps more factor categories (e.g., mobile and immobile capital goods, agricultural and mineral-bearing types of land, capital goods and skills irreversibly specialized to certain activities) and correspondingly more categories of goods. A disaggregation of Country 1 into its actual component countries would better emphasize the dominant role of Mexico and enable us to specify technology, distance, and factor endowments more exactly. It would also reveal the effects of bilateral policies on third countries.

The policy experiments break down into two categories, depending upon whether technology is transferred or not. If it is not transferred, then policy 2 (see 
tables 6 and 7 and experiment E) most narrows the unskilled wage-rate gap and therefore presumably best mitigates the incentive for unskilled labor to migrate to the United States. This policy prohibits foreign investment, migration, and technology transfer, but institutes free trade in goods and services.

It is doubtful that policy 2 narrows wage-rate differentials sufficiently to solve the American immigration problem, that is the continued influx of illegal unskilled workers. Much of the improvement over the actual situation, policy 3 (experiment $\mathrm{A}$ ), is a result of the prohibition under policy 2 of skilled labor immigration. This is probably much easier to control than unskilled labor immigration. Table 7 reveals that the slight reduction of U.S. real income under policy 2 closely matches the increase in that of Country 1. This means that skilled labor emigration to the United States is tantamount to a transfer of real income-direct foreign aid-in the same direction, a transfer which U.S. foreign aid in the opposite direction far from compensates. Mexico and the other Latin American emigration countries should therefore press the United States to restrict immigration of skilled workers. Failing that, the retrograde policy of cutting back on higher education (policy $3 \mathrm{a}$ ) achieves very nearly the same real economic benefits. Failing either of those two policies, the emigration countries should consider ways of preventing skilled workers from leaving.

The injustice of the actual situation in Latin America, in which unskilled workers pay to raise the earnings of a small elite (only to see their own earnings fall), is obvious. Political instability is inherent in this situation. Eventually, either educational opportunities in those countries will wither, or regimes capable of stemming the hemorrhaging of skilled labor will be installed. A comparison in table 7 of the relevant real wage rates under policies 3, 3a, and 2 shows that policy 3 , supporting the status quo, represents a vast transfer of income from the unskilled labor force to its few members privileged to acquire internationally vendible skills.

While policy 3 represents the de jure intent of present immigration and trade practices, the condoning of illegal, unskilled immigration plus the general trend toward freer international capital movements constitutes a real world more like that described in experiment $D$ and policies 8 and 9. These experiments reveal, surprisingly, that unrestricted unskilled labor immigration collapses the wage rate in both countries. In addition to stemming the outflow of skilled workers, the Latin American countries therefore have a strong incentive to eventually stem that of unskilled labor as well, in order to keep the U.S. wage rate from falling too low. Meanwhile, unskilled workers already in the United States have a clear interest in stopping all further immigration.

The preceding conclusions apply when the country of immigration is technologically superior in all activities. Section II analyzed the reasons for such superiority and disclosed that economic size determines the best level of technology achieved through diverting resources from current production to research and development activities. In this sense it is suboptimal for a small country to invest in too much research and development; the increase in productive efficiency would apply to too small a base to justify the foregone output. Whatever other factors cooperate in determining international technological disparities, differences in eco- 
nomic size are a sufficient explanation. The United States is huge relative to its neighbors and for that reason, if for no other, dominates them technologically and attracts their mobile production factors.

Whereas it would be inappropriate for each Latin American country to duplicate U.S. technology through its own research and development activities, it is presumably possible to transfer readymade U.S. technology to those countries, thus eliminating the primary cause of migration. Policies 11 through 20 in table 7 incorporate this experiment. They reveal, however, that while the real national income of each country rises dramatically under technology transfer, labor's real wage in each country collapses. Nevertheless, experiment G (policy 12) reveals that all benefits of complete economic integration (as under policy 20) can be achieved provided only that the accompanying changes can be accommodated. In this sense, the migration problem can be solved. It is unnecessary for people to move to another country when their home country has access to the same technology.

\section{VI \\ ACCOMMODATION AND COMPENSATION}

The immigration problem boils down to the accommodation of a large work force presently without access to adequate technology. Whether people move or technology is transferred, much more foreign labor than land and capital will be brought under the aegis of American production functions. This can only increase the relative scarcity of capital, and especially of land, and will ultimately render labor a free good everywhere.

Theoretically, of course, the increase in total worldwide output means that everyone could be better off even though unskilled labor would be a free good. Economists have long been aware of the so-called compensation principle, whereby a change is deemed desirable if the gainers compensate the losers until no one prefers the former (but some or all prefer the new) situation. ${ }^{15}$ This classic and straightforward principle has never been openly applied in the United States. Perhaps this is because economic policies are forged by political coalitions which feel no compunction to share their gains with losers and because gainers manage to conceal their identity and how they reap their gains.

General equilibrium models of the type used here directly reveal the gainers and losers via the utility measure $u$, therefore enabling the implementation of the compensation principle. The simplest way to do this is first to obtain a consensus agreement on the factoral distribution of income in the society-the percentages of total money income that go to interest income, rental income, unskilled worker compensation, skilled worker compensation, and so forth. With these factoral shares guaranteed, the next task is simply to operate a self-financing system of taxes and subsidies to maintain the stated shares in the face of any alteration in the underlying factor prices. Alterations could result, for instance, from a transfer of

15. See P. Samuelson, The Evaluation of Real Income, 2 OXrord Econ. Papers (n.s.) 1-29 (1950); Social Indifference Curves, 70 Q. J. ECON. 1-22 (1956). 
technology, a change in tariffs, or a new immigration policy. Any such policy which increases real national income should obtain unanimous political support once factor income shares are guaranteed. Political conflicts then would center only around setting those shares-a completely separate matter from that of raising aggregate income via policies affecting technology, trade, and migration.

The accommodation of either immigration or technology transfer to render immigration unnecessary clearly requires a compensatory subsidy of the unskilled wage rate in the United States, a subsidy that would be paid out of the increased earnings of capital and land. In some cases capital may also require compensation. Such subsidies should be paid only to U.S. citizens and could easily be based on $\mathrm{W}-2$ form earnings.

A wage subsidy is long overdue in any event. It is becoming obvious that the minimum legal wage rate of about $\$ 3.00$ per hour is already too high to clear the labor market. Yet, even if one earns that rate for fifty 40-hour weeks per year (which would be quite difficult), his or her income is only $\$ 6000$ per year-not half the average per capita income of the country. If that income is shared with a single dependent, the family is well below the poverty level. Yet this rate draws in millions of migrants from countries where the wages are still only a small fraction of U.S. wages.

The present de facto policy of retiring the least skilled workers by placing them on welfare as the only means of alleviating their poverty is clearly doomed to failure. It costs much more to pay a family $\$ 12,000$ a year not to work than to pay a wage subsidy of, say, $\$ 3.00$ per hour for work the family members can find. A policy of retiring U.S. families to welfare while still accepting at least half a million illegal immigrants per year is even clearer madness. A generalized wage subsidy paid to American workers that can be varied as needed in order to accommodate industrialization in Latin America and elsewhere in the Third World is the best response to the economic pressures causing migration. 